\title{
The Values of Parks to the House Residents
}

\author{
Farahwaheeda Shukur ${ }^{1}$ Noriah Othman², Abdul Hadi Nawawi ${ }^{3}$ \\ ${ }^{1}$ Centre of Postgraduate Studies, \\ $2 \& 3$ Faculty of Architecture, Planning and Surveying, \\ Universiti Teknologi Mara, 40450 Shah Alam, Malaysia \\ farah.waheeda111@yahoo.com
}

\begin{abstract}
The presence of a park in a residential area plays an important role for residents living near the park. The focus of this paper is to examine the significance of a park to the house residents. The methods used in this study include interviews with the developer and a survey administered to the residents living near the park. The main findings gathered from the survey reveal that five most important 'parkrelated factors' to house residents are (i) good park elements, (ii) conceptual or design of the park, (iii) nearness to the park, (iv) existence of a view to the park, and (v) active area of the park facing the house. Other results also indicate that shade trees, lighting and butterflies are elements preferred to be presence in a park. This research provides knowledge on the preferences of house residents and the importance of parks in a neighbourhood. The information from this research is hoped to be useful to policy makers, local authorities, urban planners, developers, corporate bodies, individuals and other related agencies involved in park and residential property development.
\end{abstract}

Keywords: park, residential, house residents, survey, park elements

eISSN 2514-751X @ 2016 The Authors. Published for AMER ABRA by e-International Publishing House, Ltd., UK.. This is an open access article under the CC BY-NC-ND license (http://creativecommons.org/licenses/by-ncnd/4.0/). Peer-review under responsibility of AMER (Association of Malaysian Environment-Behaviour Researchers), ABRA (Association of Behavioural Researchers on Asians) and $c E-B s$ (Centre for EnvironmentBehaviour Studies), Faculty of Architecture, Planning \& Surveying, UniversitiTeknologi MARA, Malaysia. https://doi.org/10.21834/aje-bs.v1i1.172 


\subsection{Background and Objectives}

The importance of parks has captured the attention of many levels of people include government, local authority, developer, planner, property buyer, and residents. Nowadays, the value of parks is recognized as an important feature to achieve comfort in life. At the same time, parks can make our cities and neighborhood more attractive places to live and work. Parks offer various opportunities to fulfill individual, social, economic and environmental benefits. For example, parks offer opportunities for individual to enrich the quality of life at all ages and abilities. For those reasons, the allocation of parks in a residential area is very important.

In Malaysia, home buyers today seem to be more selective in choosing their houses. They place equal importance to outdoor landscaping in creating a totally different lifestyle and living experience. $\mathrm{Ng}(2005)$ reported that now, park and landscape is one of the most important selling points and has become a tool for developers to entice prospective buyers. Therefore, developers who have noticed this kind of demands tend to improve the value of their property by introducing various elements to their design. Unfortunately, there are several developers who are still preserving the minimum space of green areas to save costs. Many of their housing developments are severely lacking in park space. This situation might be different if they are sensitive to the economic value of parks.

Despite many research conducted abroad, little research has been done in Malaysia on the perceptions of house residents towards parks in a rapidly growing region. Therefore, this research attempts to explore the extent to which parks give impact to the residents in Bukit Jelutong, Shah Alam, Malaysia. This research provides knowledge on the preferences of house buyers and the importance of parks in a neighbourhood. In view of this, this paper has two objectives which are to investigate park related factors that could have an effect on the value of houses and to analyse the house buyers' perspectives on park elements.

\section{0 Literature Review}

This section reviews the literature related to factors that influence house values and benefits of parks.

\subsection{Factors that influence house values}

There are many factors that affect the value of houses (Berger, 2007). The factors are physical attributes of the structure, demographic changes and the strength of the local economy. Nanda (2006) added that there are other relevant factors that will also influence house values. They are classified as locational factors, unit age of the unit, building materials, facilities, neighbourhood attributes, school district quality, property tax, employment access, and urban amenities. 
According to Kauko (2006), location has always been an important determinant of a property value. Location is determined not only by proximity to schools or shops but also by other externalities such as, accessibility to parks and green areas. For instance, the value of a house can be positively or negatively affected by its location near a residential area that is attractive, which is probably related to the quality of park equipped with good recreational facilities.

\subsection{Benefits of parks}

The values of parks to communities are many and varied. One of the benefits is for better environmental. Park areas that generally contain significant number of trees contribute in preserving and purifying the environment. As stated by Sherer (2005), trees in parks or green areas can help reduce the temperature by creating shades. Park also play a role in reducing air pollution and reduce pollutants.

Parks may also serve a social function by providing a meeting place where people or residents can develop social ties and setting. According to Waits (2008), the existence of parks in urban areas introduces nature to people through outdoor education.

Another benefit is economic. According to Rung et al. (2005), crime is lower when parks exist. Thus, settings in which there are more trees and vegetation in housing residents can inhibit crime, aggression and violence. The availability of recreation opportunities, and alternatives in the types and locations of parks are important quality of life factor for businesses when choosing where to locate and for individuals choosing a place to live (Sasidharan et al., 2001). For housing, the value of house can increase if it is adjacent to park area.

Previous research has noted that parks can also enhance sense of wellness.Walker (2004) cited that park users are found significantly healthier than non park users.

Residential areas with parks help people who engage in regular physical activity benefit from reduced risk of coronary heart disease, hypertension and weight loss.

\section{0 Methodology}

\subsection{Framework of the research}

This research was conducted in two research procedures. Figure 1 shows the flow chart of the research. In step 1, to achieve the first objective, interview sessions were held with representatives from the Property Development, Sales and Marketing and Environmental Management of Sime Darby Berhad using interview questions. The interviews were mainly conducted to obtain the heads of three departments perceptions on the values of park in their housing development and to gain actual insight to the research area and its important variables which might assist in the survey process. 
In step 2, to achieve the second objective, a residents' survey was conducted to ascertain residents' perceptions on the importance of park and their preferences. The questionnaire was carefully designed and presented in written form.

Respondents were asked to read the questions themselves and mark answers on a questionnaire. All given answers were analyzed and formatted into percentages and tables format.

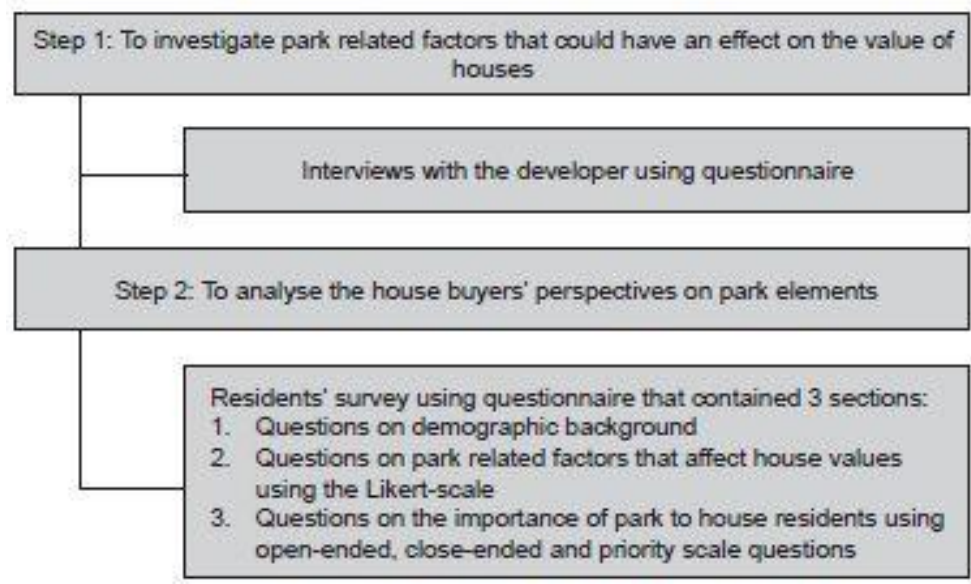

Figure 1: Flow Chart of the Research

\subsection{Research area}

The research area comprises of a residential area in Bukit Jelutong, Shah Alam,

Selangor. Bukit Jelutong Residential Area was selected due to its emergence as one of the best elite property developments projects in Klang Valley through its well planned designed that received many awards. Figure 1 shows the research area (Bukit Jelutong Residential Area).

The Bukit Jelutong Residential Area contains a variety of open spaces such as neighbourhood park, children's playground and small open green areas. This research focused on a neighbourhood park which has 10.3 acres of size. There are many facilities and elements provided in the park area such as gazebos, pergolas, jogging tracks, walkways, dustbins, benches, steps, ponds, railings and retaining walls. Figure 2 shows actual view of park. 


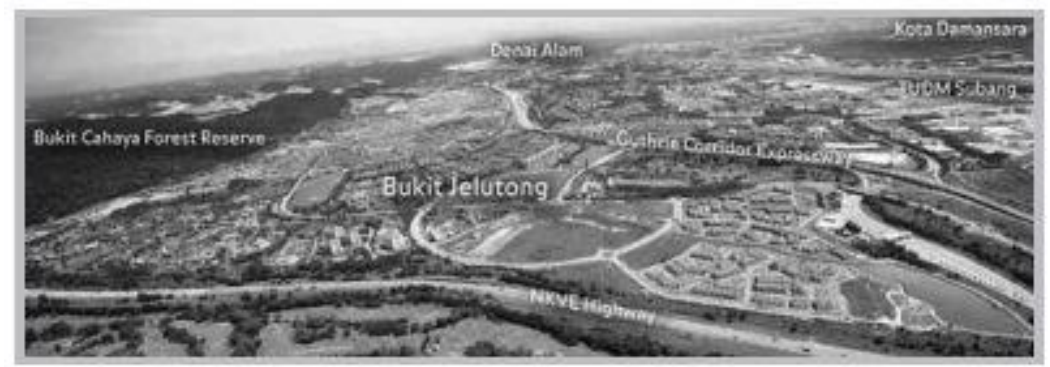

Figure 1: Research Area - Bukit Jelutong Residential Area

(Source: Sime Darby Property, 2009)

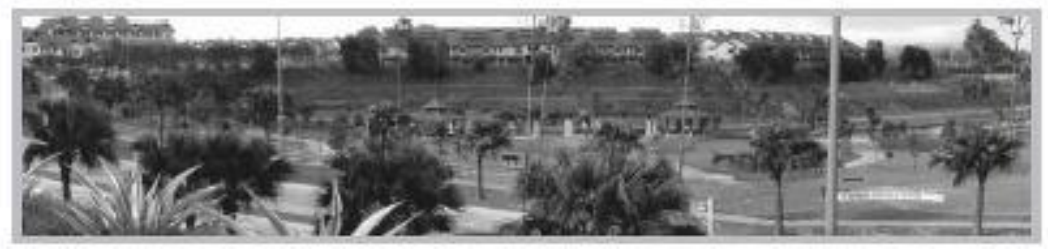

Figure 2: Actual View of park

(Source: Sime Darby Property, 2009)

\section{0 Results and Discussion}

\subsection{Interview Results}

The opinions from three representatives of Sime Darby Berhad were fairly consistent in terms of identifying important characteristics or variables of the Bukit Jelutong Residential Area. All of them agreed that parks is one of the determining factors that normally affect the value of houses in that area.

They identified that houses located near the park are highly preferred by house buyers. They opined that the location of the neighbourhood and the prestige of Bukit Jelutong also played a role in the current local scenario. When asked specifically about the importance of parks, it was identified that trees with shades and recreation facilities were highly preferred.

\subsection{Survey Results}

There are 448 numbers of respondents selected and a total of 288 questionnaires were completed at a response rate of $64.3 \%$ (Table 1$)$. 
Table 1: Survey Response Rate

\begin{tabular}{|c|c|c|}
\hline Description & Frequency & \% response \\
\hline Answered & 288 & $64.3 \%$ \\
\hline Non-answered & 160 & $35.7 \%$ \\
\hline Total & 448 & $100 \%$ \\
\hline
\end{tabular}

\section{(a) Mean Results for Park Related Factors That Affect Value of Houses}

This analysis is to achieve the first objective of the research i.e. to investigate park related factors that could have an effect on the value of houses

\section{Ranking of Mean Results for Park Related Factors}

The results show that the most influential factors are good park elements. The second most influential factor is related to conceptual or design of park. The third most influential is nearness to park. The fourth most influential factor is the existence of view to park and this is rated as important by the respondents. In addition, an active area of park facing houses is ranked as fifth (Table 2).

Table 2: Ranking of the Mean Results for Park Variables (Top 5)

\begin{tabular}{|l|c|c|}
\hline Park variables & Mean & Rank \\
\hline Good park elements & 4.43 & 1 \\
\hline Conceptual or design of park & 4.42 & 2 \\
\hline Nearness to park & 4.30 & 3 \\
\hline Existence of view to park & 4.25 & 4 \\
\hline Active area of park facing house & 4.00 & 5 \\
\hline
\end{tabular}

Notes: Important rating scale is $1=$ extremely not important, $2=$ not important, $3=$ moderate, $4=$ important, $5=$ very important.

\section{(b) Mean Results for Park Elements}

This analysis is to achieve the second objective of the research i.e. to analyse the house buyers' perspectives on parks elements. In this section, the elements of park were divided into three which are softscapes, hardscapes and wildlifes. 


\section{Ranking of Mean Results for Softcapes}

Table 3 below presents the ranking of the mean result for softscapes. It can be seen that shade trees were highly preferred.

Table 3: Ranking of the Mean Results for Softcapes (Top 5)

\begin{tabular}{|l|c|c|}
\hline Softcapes & Mean & Rank \\
\hline Shade trees & 4.64 & 1 \\
\hline Foliage shrub & 4.35 & 2 \\
\hline Grasses or turf & 4.35 & 2 \\
\hline Flowering shrub & 4.27 & 3 \\
\hline Groundcover & 3.85 & 4 \\
\hline Single trunk & 3.76 & 5 \\
\hline
\end{tabular}

Notes: Priority rating scale is 1 = lowest, 2 = lower, $3=$ moderate, $4=$ higher, $5=$ highest.

\section{Ranking of Mean Results for Hardscapes}

Table 4 below shows the ranking of mean results for hardscapes. Lightings were highly preferred according to the ranking of mean results.

Table 4: Ranking of Mean Result for Hardscapes (Top 5)

\begin{tabular}{|c|c|c|}
\hline Hardscapes & Mean & Rank \\
\hline Lightings & 4.76 & 1 \\
\hline Dustbin & 4.71 & 2 \\
\hline $\begin{array}{c}\text { Children } \\
\text { playground }\end{array}$ & 4.70 & 3 \\
\hline Bench & 4.69 & 4 \\
\hline Jogging path & 4.68 & 5 \\
\hline
\end{tabular}

Notes: Priority rating scale is $1=$ lowest, $2=$ lower, $3=$ moderate, $4=$ higher, $5=$ highest. 


\section{Ranking of the Mean Results for Wildlife}

Table 5 shows the ranking of mean results for wildlife. It was reported that butterflies were the most preferred. The second most preferred was birds. Fireflies and dragonflies were ranked third and fourth respectively. These are followed by ladybirds which was ranked the fifth.

Table 5: Ranking of the Mean Result for Wildlifes (Top 5)

\begin{tabular}{|c|c|c|}
\hline Wildlifes & Mean & Rank \\
\hline Butterflies & 4.17 & 1 \\
\hline Birds & 3.91 & 2 \\
\hline Fireflies & 3.74 & 3 \\
\hline Dragonflies & 3.44 & 4 \\
\hline Ladybirds & 3.18 & 5 \\
\hline
\end{tabular}

Notes: Priority rating scale is 1 = lowest, 2 = lower, $3=$ moderate, $4=$ higher, $5=$ highest.

\section{ODiscussions}

The objectives of this study were to investigate park related factors that could have effects on the value of houses and to analyze the house buyers' perspectives on park elements.

The results of the first objective of this study showed that there were five most important park related factors to house residents. One was good park elements, two was conceptual or design of park, three was nearness to park, four was existence of view to the park and five was active area of park facing houses. Two factors identified for other related factors were locational topography and built-up area. The results of the second objective of this study showed that shade trees for softscape, lightings for hardscape and butterflies for wildlife were highly preferred by respondents.

Good park elements were chosen as the most important factor and received the highest mean rating. Other factors were related to conceptual or design of park. If a park is not properly planned, it can often bring negative factors into the residential area. According to Richard (2008) and Paul (2006), the best design of park should consists of a good arrangement of park elements, variations of features and facilities, appearance, connections and have a safe and protection to meet the needs and people's interests. This is supported by Noah (1999) who found that park with a good character had a positive impact on people's perceptions. 
Nearness to park was viewed as important by respondents. Some respondents stated that one of the reasons to purchase the house is because the house is located near a park. This shows that the residents feel that parks bring benefits to them. They admitted that a green lung is important in their lives and this feature can attract potential house buyers to purchase a house. Their preference is supported by Elmendorf (2001). In his research, he mentioned that the value of properties close to park can influence property owners in their home purchase decisions.

The researchers also found that the existence of view to parks and active area of parks facing houses had also received attention from house buyers. These findings did support previous studies on parks and open space importance reported in the literature (Nicholls, 2002). Nicholls (2002) agreed that view is important and park with more facilities that serve active experience are more likely to be used by people.

According to respondents, shade trees, lightings and butterflies were highly preferred for elements of parks. According to Walker (1990) trees with large canopies provide shade and shelter when they are planted at park areas. For lightings, the presence of this element can provide a greater range and choice of time in which the park is accessible for use. There were high preferences for butterflies. A few respondents mentioned that they like the butterflies most. Therefore, the respondents ranked butterflies as top priority for its category.

Overall, this research found that house residents in Bukit Jelutong were aware on green and healthy environment. It is hoped that the specific needs and preferred elements by the respondents can be taken into account especially in park and residential development.

\section{0 Conclusion}

From the research findings, it can be summarized that a park has many benefits and plays multiple roles no matter where it is located, whether in residential areas, commercial areas, urban areas etc. In residential areas, a park serves as an important function in creating a sense of neighbourliness. Parks can also have a positive impact to the value of a residential property.

For future research, many suggestions can be made regarding park and property. Further research may explore on larger geographic areas containing the quantity of parks, type of open spaces and amenities i.e. greenbelt, golf course and type of houses. More case study areas are also required for comparison.

\section{Acknowledgement}

The authors would like to express gratitude to Sime Darby Foundation for funding this research. Heartiest appreciation to those involved in this study include Sime Darby 
Property, Bukit Jelutong Residents Associations, individuals, groups and other related bodies.

\section{References}

Elmendorf, W. F. (2001). The importance of leaders' and residents attitudes towards open space in developing Pennsylvania watershed. Doctor of Philosophy. Pennsylvania State University.

Kauko, T. (2006). What makes a location attractive for the housing consumer? Preliminary findings from Metropolitan Helsinki and Randstad Holland using analytical hierarchy process. Journal of Housing Built Environment, 21,159-176.

Nanda, A. (2006). Essays on the determinants of housing prices. Doctor of Philosophy, University of Connecticut.

Noah, B. (1999). Parks and recreation. A role as old as it will be new. Parks and Recreation,6-12.

Ng, A. (2005). Gamuda offers vast expanse of green to home buyers. The Star. January 17, 2005.

Nicholls, S. (2002). Does open space pay? Measuring the impacts of green spaces on property values and the property tax base. Doctor of Philosophy, Texas A \& M University.

Paul, K. (2006). Designing small parks: A manual for addressing social and ecological concerns. Journal of the American Planning Association, 72(4), 518-520.

Richard, J. D. (2008). Advocacy update: Safety on. Parks and Recreation, 43(8), 14-17.

Rung, B. A. L., Mowen, A. J. and Cohen, D. A. (2005). The significance of parks to physical activity and public health. A conceptual model. American Journal of Preventive Medicine, 28(2S2), 159-168.

Sasidharan, V., Yarnal, C., Yarnal, B. and Godbey, G. (2001). Climate change: What does it means for parks and recreation management? Parks and Recreation, 36(3), 54-60.

Sherer, P. M. (2005). The benefits of parks. Why America needs more city parks and open space. Retrieved April 4, 2009, from http://scholar.google.com.my/scholar

Waits, J. (2008). Urban green space: Is it the next financial frontier. Business Perspectives, 19(3), 36-39.

Walker, C. (2004). The public value of urban parks. Retrieved February 20, 2009 from http://scholar.google.com.my/scholar 